\title{
STUDIES OF THE ROOT SYSTEM OF COFFEA ARABICA L.
}

\section{Part II. Growth and Distribution in Catalina Clay Soil}

\section{By $J_{n}$ Guisoafre-Arrillaga and Luis A, Gosmz}

The present study involves the growth and distribution of the roots of the coffee plant in Catalina clay, one of the two principal soil types of the coffee region of Puerto Rico. It is a sequel of the study, the results of which were published in 1938 (2).

\section{Material and Methods}

Six coffee trees, of the species Coffea arabica I. generally grown in Puerto Rico, were selected at the Demonstration Farm of the Agricultural Extension Service located at Mayagîez. The trees were seven years old and averaged 273 centimeters in height, 195 centimeters in width and a trunk diameter of 4.06 centimeters (see figure 2).

The conditions under which the trees were growing are typical of the coffee groves on the island. Shade was furnished by the leguminous trees "guaba" (Inga Inga (L.) Britton) and "guama" (Inga laurina (Sw.) Willd.). The field received two or three hoe weedings a year and the coffee shade trees were lightly pruned. Light applications of inorganic fertilizers were made once a year.

The six trees selected were 8 feet apart in level land. This facilitated the work of excavation.

The method is the same described in another paper (2).

Briefly it consists of dividing the surrounding area of the tree into square foot blocks. These are then dug out separately to a depth of 12 inches per layer thus obtaining cubic foot blocks. An excavation map is prepared and to each block a number is assigned corresponding to that given to the area which it represents in the map. When the roots are removed from the soil in the blocks, by screening and washing, they are weighed. The resulting figures are represented on the corresponding area in the excavation map to show the concentration of roots.

Characteristics of Catalina clay soit. Catalina clay soil is one of the most extensive of the lateritic soil types found in the island. It is estimated that there are over 100,000 acres of this soil type on the island. It is one of the most important soils of the coffee region.

According to Bonnet (1) this is a soil of the mountain and hill lands which usually occurs where there is an annual rainfall of over 71 inches. It is a well drained soil varying in depth from 3 to 40 feet de- 
110 THE JOURNAL OF AGRICULTURE OF THE UNIVERSITY OF P. R.

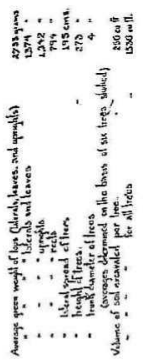

\begin{tabular}{|c|c|c|c|c|}
\hline 7 & 3 & 胥 & 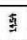 & $\frac{\Sigma}{2}$ \\
\hline$\frac{30}{35}$ & $\begin{array}{l}\frac{n}{3} \\
\end{array}$ & $\frac{\delta}{6}$ & है & 5 \\
\hline E. & $\frac{\delta}{2}$ & हE & च & 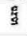 \\
\hline$\frac{96}{96}$ & 젼 & $\frac{8}{7}$ & $\frac{f}{2}$ & $\frac{n}{y}$ \\
\hline$=\frac{9 \pi}{8 \pi}$ & नै & $\frac{1}{2}$ & 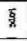 & 한 \\
\hline $\begin{aligned} 3 \\
y^{3}\end{aligned}$ & I & 8 & 2 & $\frac{2}{a}$ \\
\hline 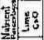 & 5 & d & 8 & $\tilde{F}$ \\
\hline $\mid \frac{5}{2}$ & 잠 & $\frac{a}{b}$ & â & $\hat{\mathrm{a}}$ \\
\hline$\frac{15}{75} \frac{5}{25}$ & 咅 & $\tilde{z}$ & 悉 & 혛 \\
\hline 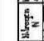 & 固 & $\frac{3}{\partial}$ & g & 8 \\
\hline$\frac{4}{8}$ & $\frac{9}{n}$ & ₹ & 3 & 立. \\
\hline
\end{tabular}

章

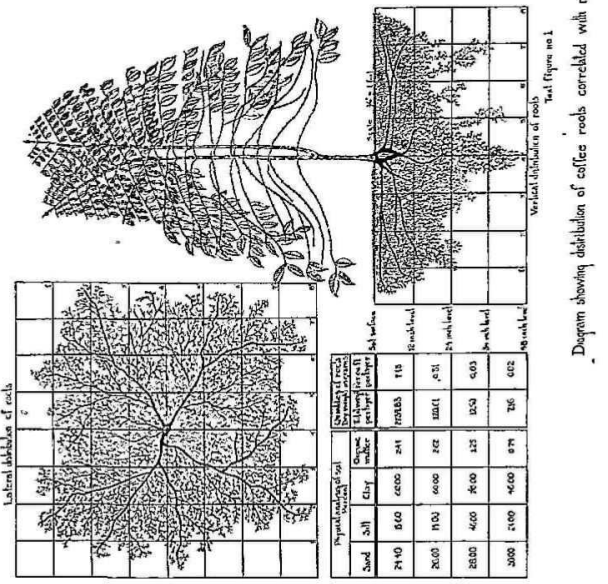


pending on the topography and the amount of annual rainfall falling on the particular region where it is found. It is derived from andesitic

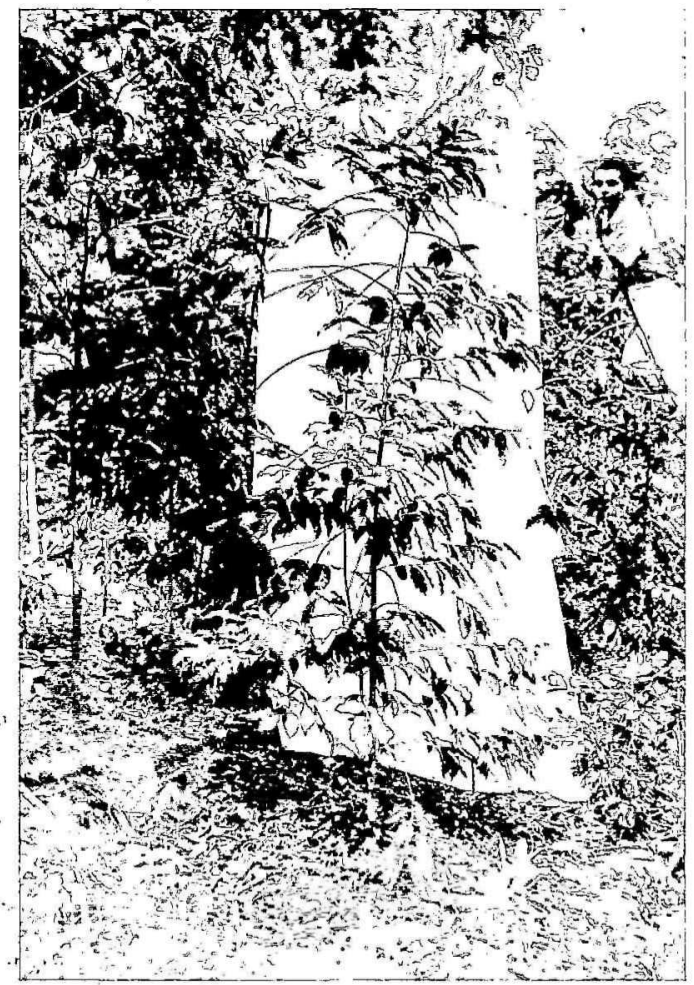

FixG. 2. Tree showing the average size and vegetative conditions of the six trees studied

tuff. Like-other lateritic soils it exhibits no sharp distinction betwcen horizons and has an acid reaction. 
In figure 3 are shown the mechanical and chemical analyses, per layer, of the soil of the experiment.

The mechanical analyses (see figure 1) revealed that there was an ample supply of organic matter in the first two layers. These averaged 2.4 and 2.6 per cent, respectively. In the third and fourth layers, however, there was a sharp reduction, the last layer averaging only 0.8 per cent of organic matter.

In gencral, the analyses revealed that there was a slight increase of total sand, and a decrease in olay with increasing depth. This shows that this soil did not exhibit, within the limits of the study, any compactness with increasing depth.

According to the chemical analyses (see figure 1) made this soil is very low in the principal plant nutrients nitrogen, phosphorus and potash. With the exception of nitrogen, which showed greater concentration in the upper layers, the quantity of plant nutrients was

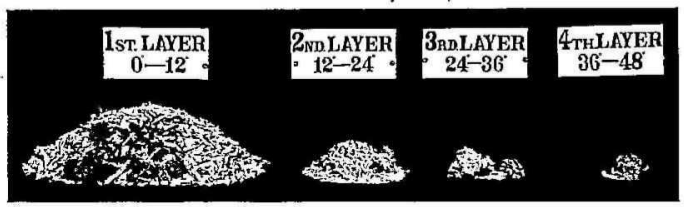

Fia. 3. Total amount of roots found per layer. (See table $\mathrm{I}$ )

practically the same at all levels. All layers proved to be very acid as revcaled by a determination of the $\mathrm{pH}$ values.

\section{Results}

The coffee trees studied were found to have 95 per cent of their root system, by weight, in the upper 12 inches of soil (table 1 ). On the same basis, 4 per cent of the roots were found in the 12 to 24 inch level while the 24 to 36 and the 36 to 48 inch levels together contained less than I per cent. The comparative distribution of the roots in each layer is shown in figure 3 .

Individual averages revealed that three trees, numbers 4,5 , and 6 . (table 1) had over 98 per cent of their roots in the first 12 inches of soil. Tree number 3 , however, had only 84 per cent of its roots in this layer.

The trecs were found to average 274 centimeters in height, 194 centimeters in lateral spread and 4.1 centimeters in trunk diameter (table 2).

The ratio of tops to roots was found to average close to 3 to 1 in five of the six trees studied. Tree number 6, however, had a ratio of nearly 5 to 1 . 


\section{Discussion}

The results obtained confurm those of a previous study where it was observed that most of the roots of the coffee plant are found in the upper 12 inches of soil.

Trees growing in Coloso clay soil, which is a poorly drained but fertile soil type with a high content of clay were found to have 94 per cent, by weight, of their root system in the upper 12 inches of soil.

TABLE 1-ROOT WEIGHTS OF 7-YEAR OLD COFFEE TREES GROWING IN CATALINA CLAY

\begin{tabular}{|c|c|c|c|c|c|c|c|c|}
\hline \multirow{3}{*}{$\begin{array}{l}\text { Isyer } \\
\text { Depth } \\
\text { inckes }\end{array}$} & \multicolumn{6}{|c|}{ Tree Number } & \multirow{2}{*}{\multicolumn{2}{|c|}{ Roots per Layer }} \\
\hline & \multirow{2}{*}{$\frac{1}{\text { grams }}$} & \multirow{2}{*}{$\frac{2}{\text { grams }}$} & \multirow{2}{*}{$\frac{3}{\operatorname{grams}}$} & \multirow{2}{*}{$\frac{4}{\text { grams }}$} & \multirow{2}{*}{$\frac{5}{\text { grams }}$} & \multirow{2}{*}{$\frac{6}{\text { grams }}$} & & \\
\hline & & & & & & & grams & per cent \\
\hline $0-12$ & 472.18 & 688.07 & 486.68 & 391.55 & 514.80 & 186.55 & $2,739.83$ & 95.12 \\
\hline $12-24$ & 13.79 & 18.35 & 79.08 & 1.25 & 8.06 & 0.08 & 120.61 & 4.19 \\
\hline $24-36$ & 3.09 & 1.77 & 5.72 & 0.28 & 2.04 & 0 & 12.90 & $0: 44$ \\
\hline $36-48$ & 0.14 & 0.59 & 5.66 & 0.70 & 0.07 & 0 & 7.16 & 0.25 \\
\hline Total.. & 489.20 & 708.78 & 577.14 & 393.78 & 524.97 & 186.63 & $2,880.50$ & 100.00 \\
\hline
\end{tabular}

TABLE 2-SIZE AND WEIGHT OF TREES

\begin{tabular}{|c|c|c|c|c|c|c|}
\hline \multirow{2}{*}{ Treo Numbar } & \multirow{2}{*}{ Height } & \multirow{2}{*}{$\begin{array}{l}\text { Lateral } \\
\text { Spread }\end{array}$} & \multirow{2}{*}{$\begin{array}{c}\text { Trunk } \\
\text { Dinmeter }\end{array}$} & \multicolumn{2}{|c|}{ Weight } & \multirow{2}{*}{$\begin{array}{c}\text { Tops to Roots } \\
\text { Ratio }\end{array}$} \\
\hline & & & & Tops & Roota & \\
\hline & centimeters & centimeters & centimeters & grams & grames & \\
\hline 1 & 283 & 183 & 4.3 & 1,415 & 489 & 2.89 \\
\hline 2 & 283 & 203 & 4.7 & 2,066 & 708 & 2.92 \\
\hline 3 & 263 & 203 & 3.9 & 1,613 & 577 & 2.80 \\
\hline 4 & 239 & 193 & 3.6 & 1,132 & 394 & 2.87 \\
\hline 5 & 293 & 213 & 4.7 & 1,443 & 525 & 2.75 \\
\hline 6 & 280 & 180 & 3.2 & 877 & 187 & 4.69 \\
\hline Total..... & 1,641 & 1,175 & 24.4 & 8,546 & 2,880 & \\
\hline Average.. & 274 & 196 & 4.1 & 1,424 & 480 & 2.97 \\
\hline
\end{tabular}

The trees here studied on Catalina clay soil, a well drained, friable but infertile soil type, were found to have 95 per cent, by weight, of their root system in the upper 12 inches of soil.

A direct relation was found between the weight of the tree tops and that of the roots in the trees growing in Catalina clay soil. Thus, the trees possessing the heaviest tops were also found to have the heaviest roots. This was not found to be true with the trees growing in Coloso clay soil where a heavy top growth was not indicative of a heavy and extensive root system. 
According to dry weights, the ratio of tops to roots was found to vary little, in the trees growing in Catalina clay soil. The average was approximately 3 to 1 . In the trees growing in Coloso clay no fixed ratio was found and the average was approximately 9 to 1 .

Differences in fertility may account for differences in the ratio of tops to roots.

. Trunk diameter seems to be the best external indicator of the comparative extent of the root system. The four trees having the greatest trunk diameter were found to have the heaviest and most extensive root system.

TABLE 3-MECHANICAL ANALYSES OF SOIL AT DIFFERENT DEPTHS

\begin{tabular}{c|c|c|c}
\hline Layer Depths & Total Bands & Bilt & Clay' \\
\cline { 2 - 3 } & per cent & por cent & per cent \\
$0^{\prime \prime}-12^{\prime \prime}$ & 24.4 & 15.6 & 60.0 \\
$12^{\prime \prime}-24^{\prime \prime}$ & 26.0 & 14.0 & 60.0 \\
$24^{\prime \prime}-36^{\prime \prime}$ & 28.0 & 46.0 & 26.0 \\
$36^{\prime \prime}-48^{\prime \prime}$ & 30.0 & 24.0 & 46.0 \\
\hline
\end{tabular}

${ }^{1}$ Determined by Bouyouvos' method.

TABLE 4-CHEMICAL ANALYSES OF THE SOIL EXCAVATED AT DIFFERENT DEPTHS

Nutrient Distribution by Layers-Percentages of Soil Weight

\begin{tabular}{|c|c|c|c|c|c|c|c|c|c|c|c|c|}
\hline $\begin{array}{l}\text { Layer } \\
\text { Depths }\end{array}$ & 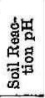 & 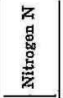 & 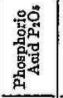 & 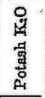 & 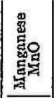 & $\begin{array}{l}\text { 。 } \\
\text { 总 } \\
\text { 总 } \\
\text { 营 } \\
\end{array}$ & 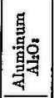 & 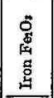 & 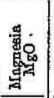 & $\begin{array}{l}0 \\
0 \\
0 \\
0 \\
\text { : }\end{array}$ & 阜 & 䇏 \\
\hline $0^{\prime \prime}-12^{\prime \prime}$ & 5.10 & $0.17 \gamma$ & 0.123 & 0.88 & 0.095 & 33.12 & 28.28 & $|19.04|$ & 0.96 & 0.99 & 16.58 & 2.4 \\
\hline $12^{n}-24^{\prime \prime}$ & 4.91 & 0.143 & 0.137 & 0.33 & 0.104 & 36.33 & 26.70 & $\mid 18.76$ & 0.93 & 1.02 & 15.49 & 2.6 \\
\hline $24^{\prime \prime}-36^{\prime \prime}$ & 4,83 & 0.095 & 0.168 & 0.33 & 0.105 & 36.09 & 26.44 & 19.99 & 0.87 & 1.00 & 14.54 & 1.2 \\
\hline $36^{\prime \prime}-48^{\prime \prime}$ & 5.11 & 0.056 & 0.122 & 0.33 & 0.08 & 96.65 & 27.75 & 18.28 & 0.80 & 0.99 & 14.44 & 0.8 \\
\hline
\end{tabular}

Italie figures indicate higher concentration of nutrients.

* Determined by Schollemberger's La Motte method.

\section{Recommendations}

The following recommendations may be made. Such trees as oranges, arocadoes and bananas which have superficial root systems and compete with the coffee plants should be eliminated from the coffee groves. Likewise, bananas, used as a temporary shade, should be destroyed as soon as they have served this purpose.

Select shade trees with deep root systems. Such trees utilize plant food, from soil layers inaccessible to the coffee trees. A great part of this is eventually deposited on the surface soil in the form of organic matter. This gains additional importance if it is remembered that 
coffee plants, having superficial roots are protected against drought by a mulch.

The results would indicate that coffee should be planted in the field at distances not less than 8 feet. In this study the root system of $7-$ year-old trees extended through a radius of 4 feet. It is assumed that the root system becomes increasingly larger with age, In close plantr ings the competition for plant food will become acute.

Trees should not be set very deep in the soil.

Loosening the surface soil, while a necessary practice to provide good aeration in such soils as Catalina and Coloso clays, should be carefully done to aroid unnecessary pruning of the roots.

\section{Summary}

1. Ninety-five per cent of the roots of coffee trees in Catalina clay soil were found in the upper 12 inches of soil.

2. Catalina clay soil is very deficient in nitrogen, phosphorus and potash.

3. A heavy and vigorous tree top was correlated with an extensive root system.

4. A fixed ratio of tops to roots, approximately 3 to 1 , was shown in Catalina clay soil.

5. The diameter of the trunk proved to be more indicative of the size of the root system than was the lateral spread of the branches or the height of the tree.

6. The lateral and vertical spread of the roots of the 7-year-old coffee trees studied was found to be slightly over four feet.

\section{Acknowledgements}

The writers are indebted to Dr. A. Rodriguez Géigel, Director of Extension, for the use of the coffee trees in the Mayaguez Demonstration Farm; to Mr. R. Charneco, Extension Agent, for valuable cooperation; to Mr. J. O. Carrero, chemist of the Puerto Rico Agricultural Experiment Station (U.S.D.A.); to Mr. R. Rodriguez Torrent and Mr. Leonardo Igaravidez, assistant chemists, for chemical and physical analyses;' and to Mr. Robert Cole of the Puerto Rico Agricultural Experiment Station (U.S.D.A.) for the photographs taken.

\section{Resumen}

1. FI nuevo método desarrollado por los autores en el estudio del sistema radical del cafeto en suelos del tipo Coloso (2) fué usado nuevamente para el estudio de las raíces de dicha planta en suelos del tipo Catalina. 


\section{THE JOURNAL OF AGRICULTURE OH THE UNTVERTTY OF P. R.}

2. Este nuevo método, brevemente descrito, requiere la excavación de bloques de tierra de un pie cúbico cada uno en el área asignada para cada arbusto. De esta tierra se separan las raíces que se lavan y se secan para determinar su peso. La excavación se hace por capas de un pie de profundidad y se continúa hasta aquella profundidad en la cual ya no existen más raíces. La excavación se hace de acuerdo con un mapa que representa el área asignada a cada arbusto con la ayuda del cual se puede determinar la posición exacta de las raíces obtenidas de cada bloque y la cantidad de raices existentes enlas diversas profundidades excavadas y la penetración vertical y lateral de las mismas.

3. El 95 por ciento de las raices se encontraron en las 12 primeras pulgadas del suelo.

4. El suelo Catalina es muy deficiente en los principales elementos nutritivos y ello contribuye grandemente al bajo rendimiento de café obtenido por cuerda. La aplicación de fertilizantes indudablemente mejoraría la productividad de este suelo.

5. El desarrollo vigoroso de la parte aérea del cafeto depende de un sistema radical extensivo.

6. La proporción del peso de la parte aérea al peso de las raíces es constante y según los resultados obtenidos en este estudio es de 3 a 1.

7. Al seleccionar arbustos de partes áreas y sistemas radicales vigorosos y bien desarrollados, el diámetro o grueso del tronco es mejor indicación de estas características que la altura o la expansión lateral de las ramas del arbusto.

8. El sistema radical del cafeto es completamente superficial y tiene en general la forma de un cono invertido. A los siete años se encontró que las raíces se extendían cuatro o más pies radialmente y que la penetración vertical era también de 4 pies. La siembra en el campo debe hacerse, pues, a distancias no menores de $8 \times 8$ pies.

9. De acuerdo con los resultados obtenidos se hacen las siguientes recomendaciones:

(a) La distancia minima de siembra para arbustos de café debe de ser de $8 \times 8$ pies, pues a la temprana edad de 7 años ya los sistemas radicales se entrelazan cuando se siembra a esa distancia y es de suponer que el grado de competencia por los alimentos nutritivos del suelo va aumentando a partir de esa edad.

(b) Debe eliminarse el número excesivo de árboles de sombra y de plantas de guineos, plátano, chinas, naranjas, aguacate, etc.,debido a la competencia por alimentos entre éstos y el cafeto, especialmente plantas con el sistema radical superficial.

(c) La conservación de la humedad y de la materia orgánica es de importancia extrema y se puede lograr amontonando toda clase de 
hojarasca alrededor del arbusto y haciendo hoyos entre las calles para enterrar la materia orgánica.

(d) Los hoyos preparados en el campo no tienen que ser muy profundos, pero sí lo más ancho posible. Estos deben llenarse solamente con tierra de la superficie.

(e) Siendo superficial el sistema radical del cafeto, es recomendable que al sembrarse se coloque el arbolito en el hoyo a la misma profundidad que se encontraba en el vivero para asi darle oportunidad a las raíces para que se desarrollen en la capa más suelta y más rica del terreno.

(f) Los análisis químicos demostraron que el suelo Catalina es -bastante pobre en materias minerales necesarias para el mejor desarrollo de las plantas. Por lo tanto, para obtener buenos rendimientos de café, es necesario el uso de abonos químicos.

(g) Las aplicaciones de abono no necesitan hacerse profundas, puesto que la mayoría de las raíces se encuentra en la capa superficial. Para aplicar el abono basta con remover el suelo ligeramente alrededor del arbusto, mezclando abono y tierra convenientemente. En caso de que los arbustos estén en terreno quebrado el abono se aplicará en las terrazas individuales o en las minas para evitar que sea lavado por las lluvias.

(h) Es conveniente promover la aeración en los terrenos de vez en cuando ya que esta operación facilita los procesos biológicos y físico químicos. Esta labor puede efectuarse con azadas de picar si el terreno es llevadero o con tenedores verticales cuando el terreno es muy quebrado, teniendo siempre la precaución de no acercarse mucho a los troncos y raíces principales para evitar la mutilación de un número excesivo de éstas.

\section{LITERATURE CITED}

(1) Bonnet, J. A. The nature of laterization as revealed by chemical, physical, and mineralogical studies of a lateritic soil profile from Puerto Rico. Soil Science 48 (1): 25-29. 1939.

(2) Guiscafré-Arrillaga, J. and I. A. Gómez. Studies on the root system of Coffea arabica L. Part I. Environmental Conditions Affecting the Distribution of Coffee roots in Coloso clay. Jour. Agr. Unir. P. R. 22(2): 227-262. 1938. 